\title{
Marketing Model of Professional Orientation
}

\author{
Vera Rogova
}

\begin{abstract}
In the article it's discussed the possibility and feasibility of the marketing approach in the organization and implementation of professional orientation of students as potential students of universities. The tasks facing modern higher education organizations in Russia are largely similar in nature to the problems of commercial organizations, which allows us to consider both the existing practical experience and to use the existing theoretical Foundation of marketing to solve the problems facing Russian higher education today

Index Terms: training of engineering and technical personnel, marketing of non-profit organizations, traditional and marketing model of career guidance, marketing tools
\end{abstract}

\section{INTRODUCTION}

The peculiarity of the modern stage of economic development makes it particularly important to train highly qualified specialists in the field, which in the world practice is designated by the abbreviation STEM (Science, Technology, Engineering, Mathematics). It is the graduates of these areas of training and specialties (mainly engineering) that are most necessary for the development of advanced technological solutions that provide an innovative type of economic growth. According to the Global innovation index in terms of the share of University graduates in scientific and engineering specialties, Russia occupies a fairly high 13th position in the world [1], which, according to experts, is a strong point of the national innovation system. At the same time, many domestic experts believe that today the Russian economy is not provided with the required number and quality of personnel that meet modern requirements, the required reproduction of engineering and technical personnel, not only in quantity but primarily in quality, does not occur. And this fact is among the main reasons for the slow transition to an innovative economy [2, 3].

According to the statistics of education in recent years, more than $30 \%$ of those enrolled in training are contingent engineering and technical areas of training and specialties [4]. At the same time, the results of the survey of applicants with some discrepancies in the data for different regions, in General, show that only a small part chooses engineering and technical areas of training and specialty out of interest in engineering. A significant number of applicants to universities choose technical education because of the relative larger number of budget places, which increases the likelihood of entering the University on a budgetary basis. The consequences of this situation are quite obvious: lack of interest in learning, low academic performance, a high percentage of deduction, both because of poor performance

Revised Manuscript Received on July 09, 2019.

Vera Rogova, MIREA - Russian Technological University, Moscow, 119454 Russia and on their own, that "does not cling." And among those who complete their studies, there is a high percentage of those who do not go to work in their specialty, and if they do, they do not meet the requirements of employers.

\section{RESEARCH METHOD}

The problem considered in this article was investigated by the author with the use of empirical research methods, including, first of all, observation of applicants, educational organizations and employers; comparison of the results of the implementation of various models of career guidance, as well as an experiment on the implementation of individual marketing approaches to career guidance on the basis of a specific educational organization of higher education.

\section{RESULTS AND ANALYSIS}

The problem of training engineers and technicians is undoubtedly of a systemic nature. However, the modernization of the material and technical base of educational organizations, and the development of competencies of teaching staff, and active interaction and high interest and participation in the training of employers can give the expected result, if entering the engineering and technical areas of training and specialty will be really passionate and focused on engineering and technical activities in the future, internally motivated to receive engineering and technical education. Therefore, it is very important that at the stage of deciding on whom to go to study, the choice of high school students was not made in favor of a profession that is fashionable, popular, prestigious or most highly paid, and the score is due to the direct interest in it.

In a situation of low prestige of engineering activities (due to many factors of economic nature) and at the same time the high demand of the national economy in engineering and technical personnel, it is necessary to attract high school students, to awaken their interest in technology, maybe even to reverse the existing ideas. Obviously, the greatest opportunities for this are provided by the professional orientation of high school students. That is, there is a task, in many ways similar to that which is solved by any commercial company, seeking to promote a certain product and interest them to a potential consumer. But if, having achieved success (having interested and sold the product), a commercial company achieves a result that can be considered as the final, then attracting students to its University and certain educational programs, the educational organization only achieves its current goals. In order to achieve the desired end result in terms of the socio-economic function of education, it is necessary to 


\section{Marketing Model of Professional Orientation}

ensure, using market terminology, the emotional loyalty of future students to the chosen specialty. It is with this interpretation that the task of career guidance acquires a marketing orientation, and the subject of marketing activity in this case will be a higher education institution.

Carrying out career guidance work among schoolchildren is not a new thing. However, in the framework of the traditional model, involving the one-way transmission of information to high school students about the features of a particular type of professional activity, which is carried out mainly by teachers of secondary school and is actually impersonal in nature, without taking into account the individual, including motivational features of the future student, the possibility of achieving the desired result is very limited.

The use of marketing in higher education today is quite common. Being involved in the competition, many educational organizations use, and sometimes very effectively, marketing tools to achieve their organizational goals.

There are a lot of fundamental works and researches, both foreign and domestic experts, devoted to questions of marketing in non-profit sector and including, in the sphere of education [5-9]. The problem considered in this article assumes deeper penetration of marketing in management of higher education institution as the tool of achievement not only the direct purposes of the educational organization, but also as the tool promoting effective realization of social and economic function of the higher education.

The essence of the marketing model of career guidance is to offer each high school student exactly what he is interested in while striving to interest in those types of professional activities and professions that are currently most in demand by the national or regional economy. The universities have the greatest opportunities to solve this dual problem, which, implementing certain educational programs, have not only professional specialists, but also the appropriate material and technical base.

In their desire to Orient high school students, taking into account their interests, universities are building various strategies for interaction with high school. In this regard, the point of view is noteworthy, according to which three types of interaction strategies can be distinguished: "random connections", "use of each other" and "absorption of the school by the University" [10]. The implementation of the last of these strategies creates the greatest opportunities for "penetration into the school", carrying out various career guidance activities with students using traditional marketing tools. It should be noted that until recently the main object of career guidance were the final classes of the school. However in recent years, the "depth of penetration into the school" is increasing, and in the ongoing activities seek to involve students who have until the release of 2-3 years.

The initial element of the marketing model of career guidance, and at the same time the most reasonable approach, creating the basis for achieving the goals, is the segmentation of high school students by groups of dominant interests. Using the technology of market research, get information about the professional interests and needs of future students. As a rule, the University interacts with several schools, which makes it possible to cover a sufficiently large contingent, from which the results of the study are formed profile groups of students, for subsequent work with each of which is developed its own program. Such a program usually includes such components as marketing activities for high school students; group and personal work with students, taking into account their abilities and needs, as well as the interest of the University in it; increasing the loyalty of potential students by "drawing" them into the life of the University: providing information about the news of the University, student life, involvement in events held for students, competitions, competitions, etc.

The focus of the activities can and should be different and moderately aggressive (so as not to alienate high school students). Logical and providing the desired result is a sequence that begins with the activities of information orientation, then - specialized activities with the active involvement of advertising tools (excursions to the production, meetings with practitioners, graduates who have achieved great professional success, etc.). Advertising is not only the engine of trade. In solving the problems of career guidance, it is also indispensable and, if used correctly, can break the stereotypes of high school students, to demonstrate the strengths and benefits of a particular in their eyes "unattractive" profession. Increasing with the help of events profile orientation interest, move on to motivating the actions which will allow to consolidate an interest, increase confidence in the correct choice.

The platforms for interaction between universities and potential applicants and the implementation of the marketing model of professional orientation are traditionally schools, universities, as well as the Internet space in which work should be carried out both on the official websites of educational institutions and on various thematic Internet portals. Moreover, given the characteristics of the modern young generation as a "digital generation", information and communication tools of interaction and impact are becoming more significant and effective, which is not left without attention and specialists in the field of marketing in higher education [11].

The results of the implementation of the marketing model of career guidance become apparent only in the medium and long term. In the short term, they can be judged by the quality of the contingent of students, which is manifested in the level of performance, reducing the percentage of deductions, project and research activity of students, involvement of students by employers in the face of specialized enterprises in solving production problems, etc.

\section{Conclusion}

In conclusion, it would like to note that the professional orientation of students as a tool to promote the correct and informed professional choice, a problem worthy of special research. It is 
obvious that the marketing approach is only one of the possible. Nevertheless, the application of this approach, in our opinion, will significantly improve the quality of University entrants, and hence the quality of training, so necessary for the economic development of the country.

\section{Conflict of Interest}

The authors declare no conflict of interest.

\section{REFERENCES}

[1] "Global innovation index" URL: https://www.globalinnovationindex.org/

[2] G.P. Litvintseva, N.G. Nizovkina, N.A. Gakhova, " Training of engineering and technical personnel, taking into account the achievements of modern economic science” Education and Science. Vol. 19, № 2. 2017. P.101-123.

[3] V.A. Rogova, "Personnel problems of high technology development in Russia in the mirror of the Global innovation index" Rossiyskiy tekhnologicheskiy zhurnal (Russian Technological Journal). 2018, 6(4), p. 105-116. (in Russ.)

[4] "Education in Russia - 2018. Statistical bulletin" Moscow, MIREA Russian Technological University. 2018. 422 p.

[5] P. Druker, Management in a non-profit organization: principles and practice. Moscow, Wiliams. 2007. 304 p.

[6] P. Kotler K. Fox, Strategic Marketing for Educational Institutions. 1995. Prentice Hall, Englewood Cliffs, NJ.

[7] P. Kotler, A.R. Andreasen, Strategic marketing of non-profit organizations Rostov-na-Donu, "Feniks". 2007. 854 p.

[8] P. Naudea, J. Ivy "The marketing strategies of universities in the United Kingdom" The International Journal of Educational Management, 1999, № 13/3. pp. 126-134.

[9] A.P. Pankrukhin, Marketing of educational services. URL: http://www.marketologi.ru.

[10] G.N. Prozumetova, "Potential of interaction between universities and schools: empirical models" Vestnik TSU. 2012. № 358. P. 182-188.

E. Constantinides, M.C.Z. Stagno, "Higher education marketing: A study on the impact of social media on study selection and university choice" International Journal of Technology and Education Marketing (IJTEM). 2012. Vol. 2, № 1. P.41-58. 